\title{
Robot Device
}

National Cancer Institute

\section{Source}

National Cancer Institute. Robot Device. NCI Thesaurus. Code C50152.

A mechanical device designed to perform an automated action. 